\title{
Rancang Bangun Sistem Pakar Diagnosa Penyakit Tanaman Stroberi Menggunakan Metode Certainty Factor Berbasis Web
}

\author{
Nina Mauliana Noor Fajriah ${ }^{* 1}$, Yufis Azhar ${ }^{2}$, Gita Indah Marthasari ${ }^{3}$ \\ 1,2,3Teknik Informatika/Universitas Muhammadiyah Malang \\ ninamauliana@gmail.com*
}

\begin{abstract}
Abstrak
Sistem Pakar merupakan sebuah sistem yang bekerja nya mengambil pengetahuan seseorang ke dalam komputer yang nanti nya diolah sedemikian rupa untuk mewakili kemampuan dalam menyelesaikan masalah menyerupai seorang pakar. Metode yang dipakai dalam pembuatan aplikasi ini adalah metode Certainty factor. Metode ini sangat tepat digunakan untuk sistem pakar dalam menentukan suatu entitas apakah absolut atau tidak dalam mendiagnosa, misalnya sistem pakar diagnosa penyakit tanaman stroberi. Aplikasi ini memungkinkan pengguna nya untuk mendiagnosa penyakit pada tanaman stroberi sebelum melakukan tindakan lebih lanjut. Aplikasi ini dibangun dengan memakai PHP sebagai bahasa pemograman nya MySQL sebagai penyimpanan datanya. Pada saat pengguna melakukan konsultasi aplikasi akan menampilkan gejala-gejala penyakit dan pengguna dapat memilih tingkat keyakinan dari gejala penyakit yang dipilih. Hasil akhir aplikasi ini berupa jenis penyakit berdasarkaan inputan gejala yang dipilih serta cara penanganan nya.
\end{abstract}

Kata Kunci: Sistem Pakar, Penyakit Tanaman Stroberi, PHP, MySQL, Diagnosa

\begin{abstract}
Expert system is one of the Al Development fields. Al (Artificial Intelligence) is part of a computer science which used the computer to imitate the human thoughts and behavior. The usage of a method in Expert System is very important. Thus, the most compatible method to use is the Certainty Factor method. This method is suitable to be used on Expert System to measure things and diagnosed it, will it be very sure or unsure. For example, Expert System to diagnose disease on strawberry plants. This software allows the user to diagnose the disease on strawberry plants before taking a further action. This software is using PHP programming language and store the data using MySQL system database. When the user consulting to the software, the software will show the symptoms of the disease and the user can choose the level of certainty from the chosen disease symptom. The final result from the software is a form which includes the guide of how to take the measurement of the disease based on the chosen symptoms.
\end{abstract}

Keywords: Expert System, Diagnosed, Strawberry Plants Disease, PHP, MySQL

\section{Pendahuluan}

Dewasa ini, kemajuan pada bidang teknologi berjalan begitu cepat, sehingga menuntut kita untuk selalu bisa bergerak cepat dan siap. Masyarakat harus bisa mengikuti segala bentuk kemajuan tersebut di berbagai bidang tak lepas dari sentuhan teknologi termasuk juga bidang perkebunan dan pertanian yang merupakan salah satu sumber mata pencarian kebanyakan masyarakat Indonesia. Salah satu pemanfaatan teknologi komputer yaitu dapat digunakan untuk sistem pakar. Sistem Pakar merupakan sebuah sistem yang bekerja nya mengambil pengetahuan seseorang ke dalam komputer yang nanti nya diolah sedemikian rupa untuk mewakili kemampuan dalam menyelesaikan masalah menyerupai seorang pakar. Metode yang digunakan dalam pembuatan sistem pakar ini adalah certainty factor. Metode ini sangat tepat di implementasikan untuk sistem pakar dalam menentukan suatu entitas apakah absolut atau tidak dalam mendiagnosa, misalnya sistem pakar diagnosa penyakit tanaman stroberi. Jenis Stroberi yang paling banyak dijumpai dan tersebar di Indonesia adalah Fragaria chiloensis L. [1]. Dalam pembudidayaan stroberi tidak mungkin tidak terdapat tantangan dan hambatan berupa hama dan penyakit. Bahkan tidak jarang para petani stroberi mengalami kerugian karena banyak tanaman stroberi yang mati atau gagal panen. Diagnosa terhadap penyakit pada tanaman stroberi yang terjangkit suatu penyakit harus dilakukan dengan cepat dikarenakan penyakit pada tanaman 
tersebut dapat dengan cepat menyebar serta menyerang keseluruh lahan pertanian. Keterbatasan jumlah pakar serta pengetahuan petani perkebunan dan juga masyarakat umum yang juga tertarik dalam membudidayakan stroberi akan pencegahan juga penanganan terhadap tanaman yang terserang penyakit masih kurang, Sehingga dibutuhkan media untuk menyampaikan informasi mengenai penanganan dan pencegahan terhadap penyakit tanaman stroberi tersebut. Informasi dapat diperoleh melalui Sistem Pakar berbasis web sebagai pengganti peran manusia.

\section{Metode Penelitian}

\subsection{Sistem Pakar}

Sistem Pakar merupakan sebuah sistem yang bekerja nya mengambil pengetahuan seseorang ke dalam komputer yang nanti nya diolah sedemikian rupa untuk mewakili kemampuan dalam menyelesaikan masalah menyerupai seorang pakar.[2]. Hal utama yang pasti ada pada setiap sistem pakar adalah basis pengetahuan, mesin inferensi, dan antarmuka program.

\subsection{Certainty Factor}

Faktor Kepastian (certainty factor) mendefinisikan kepercayaan berdasarkan fakta atau penilaian dari pakar[3]. Faktor kepastian menggunakan bobot untuk mengimpretasikan derajat keyakinan seorang pakar akan suatu data. Dirumuskan pada Persamaan 1, Persamaan 2, Persamaan 3 dan Persamaan 4 dan di interpretasikan pada Tabel 1 di bawah ini.

$$
\begin{gathered}
\mathrm{CF}(\mathrm{H}, \mathrm{E})=\mathrm{MB}(\mathrm{H}, \mathrm{E})-\mathrm{MD}(\mathrm{H}, \mathrm{E}) \\
\mathrm{CF}(\mathrm{H}, \mathrm{e})=\mathrm{CF}(\mathrm{E}, \mathrm{e}) * \mathrm{CF}(\mathrm{H}, \mathrm{E}) \\
\mathrm{CFC}(\mathrm{CF} 1, \mathrm{CF} 2)=\mathrm{CF} 1+\mathrm{CF} 2(1-\mathrm{CF} 1)
\end{gathered}
$$

Tabel 1. Interpretasi Nilai CF

\begin{tabular}{lc}
\hline \multicolumn{1}{c}{ Uncertain Term } & CF \\
\hline Definitely not (Pasti Tidak) & -1.0 \\
Almost certainly not (hampir pasti tidak & -0.8 \\
Probably not (kemungkinan besar tidak) & -0.6 \\
Maybe not (mungkin tidak) & -0.4 \\
Unknown (tidak tahu) & 0.2 to 0.2 \\
Maybe (mungkin) & 0.4 \\
Probably (kemungkinan besar) & 0.6 \\
Almost certainly (hampir pasti) & 0.8 \\
Definitely (pasti) & 1.0 \\
\hline
\end{tabular}

Untuk menghitung akurasi sistem pakar dan diagnosa pakar maka menggunakan Persamaan 4.

$$
\text { Nilai akurasi }=(\text { jumlah data akurat }) /(\text { jumlah seluruh data }) \times 100 \%
$$

\subsection{Analisis Kebutuhan Fungsional}

Pada Gambar 1 diatas terdapat 2 aktor, yaitu Member yang dapat melakukan konsultasi penyakit, Admin yang bertindak sebagai pengelola sistem yang dapat melakukan pengelolaan terhadap data admin, data member, kelola informasi, kelola data gejala, kelola data penyakit. data pengetahuan dan melihat hasil konsultasi 


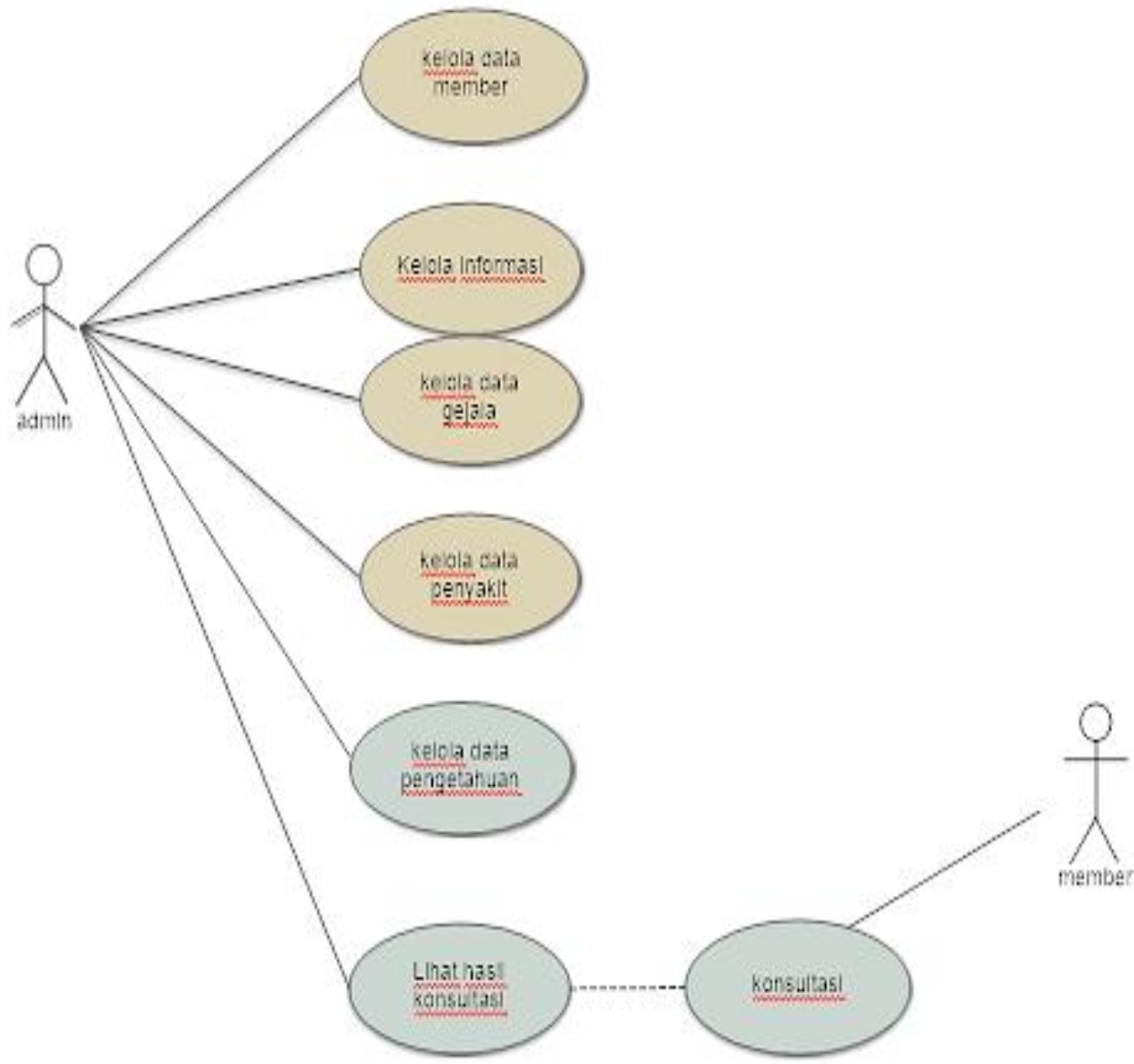

Gambar 1. Usecase Diagram Sistem Pakar

\subsection{Diagram konteks}

Gambar 2 adalah diagram konteks dari program sistem pakar diagnosa penyakit pada tanaman stroberi.

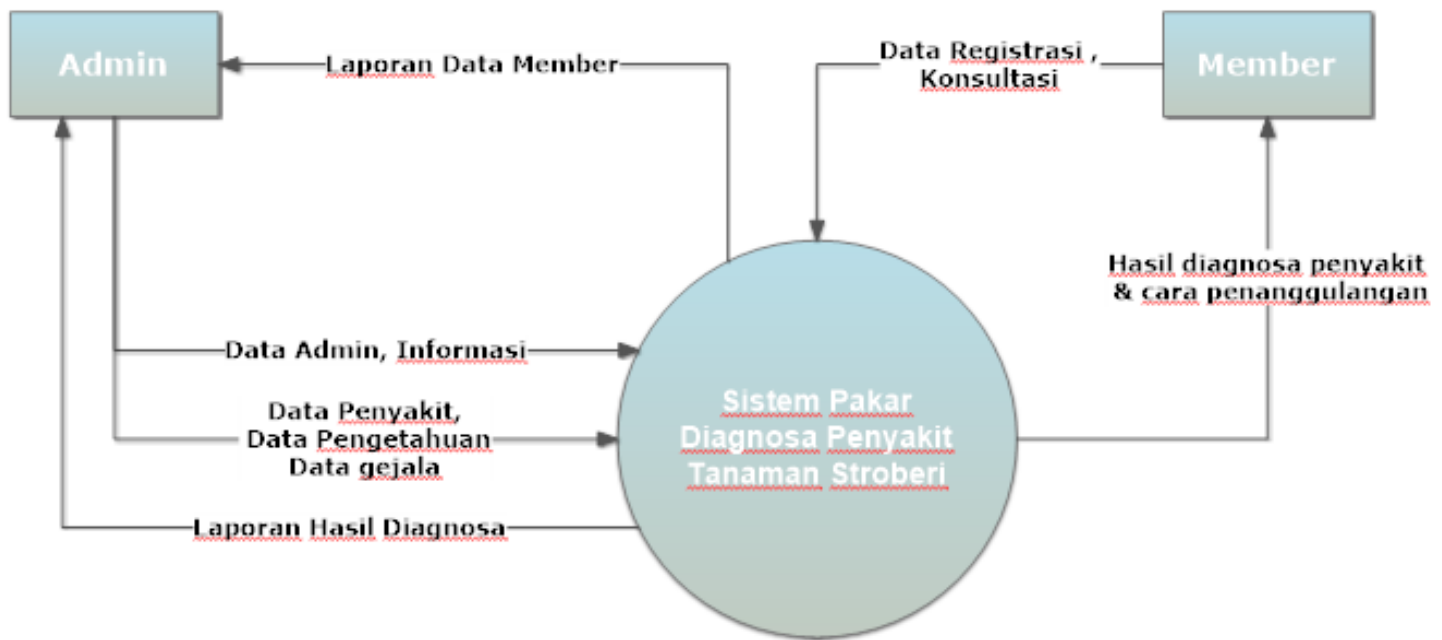

Gambar 2. Diagram Konteks

\subsection{Diagram Alur}

Diagram alur adalah langkah urutan/prosedur dari sebuah program, Gambar 3 adalah diagram alur dari program sistem pakar diagnosa penyakit pada tanaman stroberi. 


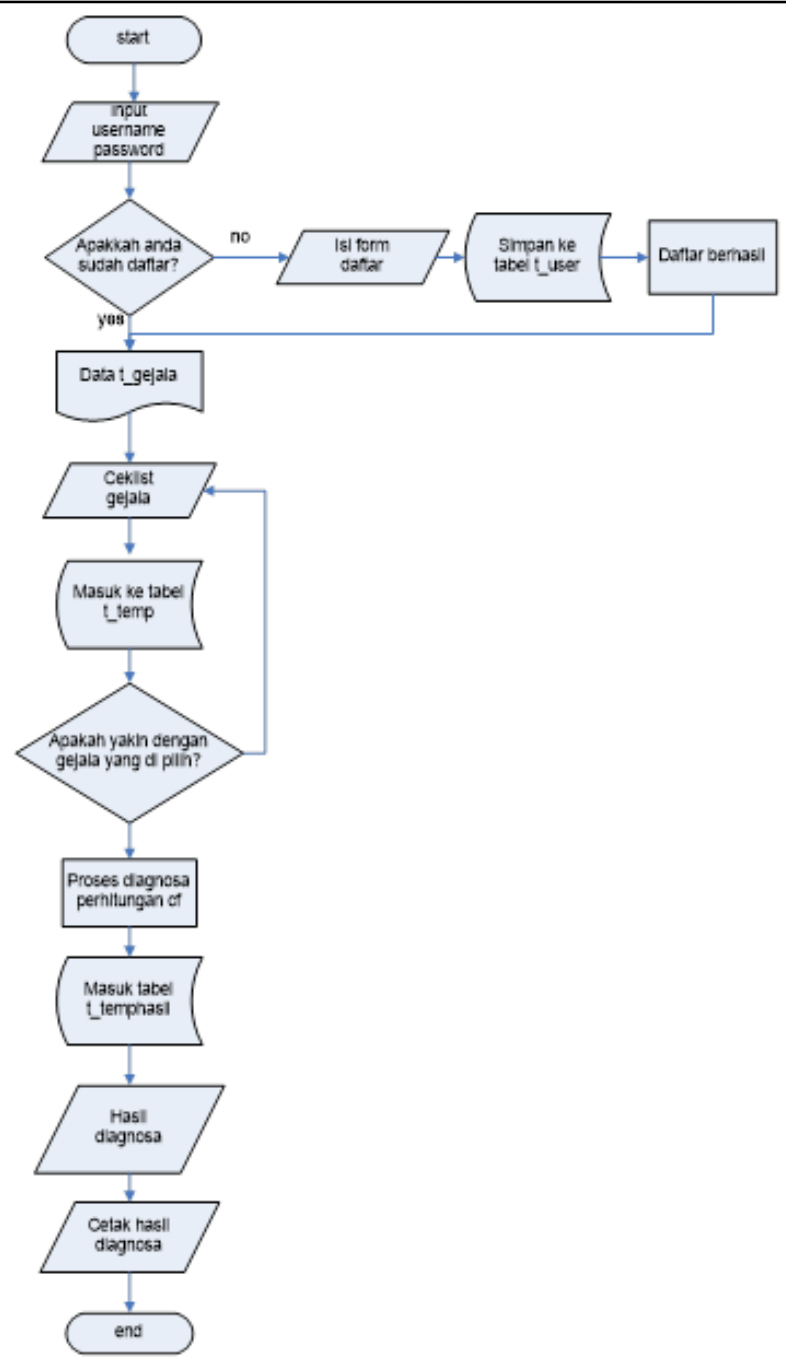

Gambar 3. Diagram Alur

\subsection{Analisis Kaidah Produksi}

1. Penyakit Empulur Merah

Rule 1 : IF Daun tidak segar THEN Empulur Merah

Rule 2 : IF Daun Kadang layu THEN Empulur Merah

Rule 3 : IF Daun tanaman yang layu menunjukan warna hijau THEN Empulur Merah

Rule 4 : IF Tanaman Layu Kemudian Mati THEN Empulur Merah

Rule 5 : IF Tanaman tumbuh kerdil THEN Empulur Merah

2. Penyakit Layu Vertilicium

Rule 1 : IF Daun berbercak kuning sampai coklat THEN Layu Verticilium

Rule 2 : IF Daun Kadang layu THEN Layu Verticilium

Rule 3 : IF Tanaman Layu Kemudian Mati THEN Layu Verticilium

3. Penyakit Embun Tepung

Rule 1 : IF Bagian terserang adalah daun THEN Embun Tepung

Rule 2 : IF Bunga akan mengering kemudian gugur THEN Embun Tepung

Rule 3 : Daun tertutup lapisan putih tipis seperti tepung THEN Embun Tepung

Rule 4 : IF Daun tiba-tiba gugur THEN Embun Tepung

4. Penyakit Noda Merah

Rule 1 : IF Bercak berwarna merah keunguan THEN Noda Merah

Rule 2 : IF Bercak juga terdapat pada tangkai buah THEN NOda Merah

Rule 3 : IF Daun berwarna ungu tua THEN Noda Merah

Rule 4 : IF Diameter bercak-bercak 1-5 mm THEN Noda Merah

Rule 5 : IF Terdapat bercak-bercak kecil bulat pada daun THEN Noda Merah

REPOSITOR, Vol. 1, No. 1, November 2019: 47-58 


\section{Penyakit Busuk Rizopus}

Rule 1 : IF Bagian banyak terserang adalah buah THEN Busuk Rizopus

Rule 2 : IF Buah Berair THEN Busuk Rizopus

Rule 3 : IF Buah berwarna coklat muda THEN Busuk Rizopus

Rule 4 : IF Mengeluarkan cairan putih saat buah ditekan THEN Busuk Rizopus

Rule 5 : IF Buah Terinfeksi tertutup miselium jamur berwarna putih THEN Busuk Rizopus

Rule 6 : IF Spora berwarna hitam THEN Busuk Rizopus

\section{Penyakit Hawar Daun}

Rule 1 : IF Daun terbentuk noda bulat THEN Hawar Daun

Rule 2 : IF Pada noda dikelilingi warna merah ungu THEN Hawar Daun

Rule 3 : IF Membentuk luka mirip huruf V THEN Hawar Daun

Rule 4 : IF Bagian terserang adalah daun THEN Hawar Daun

\section{Penyakit Daun Gosong}

Rule 1 : IF Daun berbercak bulat telur sampai bersudut tidak teratur THEN Daun Gosong

Rule 2 : IF Pada noda dikelilingi warna merah ungu THEN Daun Gosong

Rule 3 : IF Disekitar bintik meluas daerah yang berwarna kekuningan hingga keunguan THEN Daun Gosong

Rule 4 : IF Daun yang tua menjadi suram dan tumbuh merana kemudian mati (gugur) THEN Daun Gosong

\section{Penyakit Virus}

Rule 1 : IF Tanaman tumbuh kerdil THEN Virus

Rule 2 : IF Tanaman Menjadi Abnormal THEN Virus

Rule 3 : IF Daun menjadi kuning sepanjang tulang daun THEN Virus

Rule 4 : IF daun tampak totol-totol THEN Daun Gosong

\section{Penyakit Tip Burn}

Rule 1 : IF Ujung daun nampak terbakar THEN Tip Burn

Rule 2 : IF Daun tidak segar THEN Tip Burn

Rule 3 : IF Pertumbuhan tanaman menjadi terhambat THEN Tip Burn

\section{Hasil Penelitian dan Pembahasan}

Berikut ini merupakan pembahasan secara rinci mengenai hasill dari Analisa, perancangan dan implementasi sesuai dengan tahapan-tahapan yang dilakukan dalam pembuatan sistem pakar.

\subsection{Implementasi Antar Muka}

Implementasi antarmuka menggambarkan tampilan dari aplikasi yang dibangun yaitu implementasi antarmuka sistem pakar diagnosa penyakit tanaman stroberi berbasis web menggunakan metode certainty factor.

\subsubsection{Halaman Utama User}

Gambar 4 adalah tampilan utama aplikasi ini yang mana terdapat menu Home, Konsultasi, Glosari, Informasi, dan juga form login.

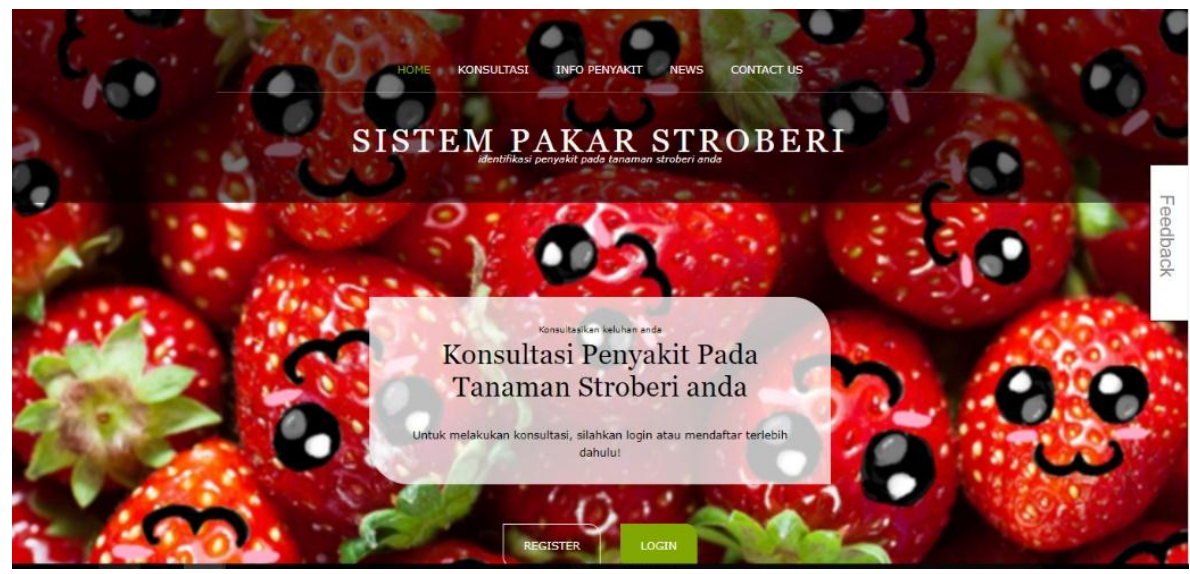

Gambar 4. Tampilan Halaman Utama 


\subsubsection{Halaman Konsultasi}

Gambar 5 adalah tampilan menu konsultasi untuk member. Pada Halaman konsultasi, member dapat memilih gejala dengan cara mencetang gejala yang sesuai dan memilih tingkat gejala yang dialami.

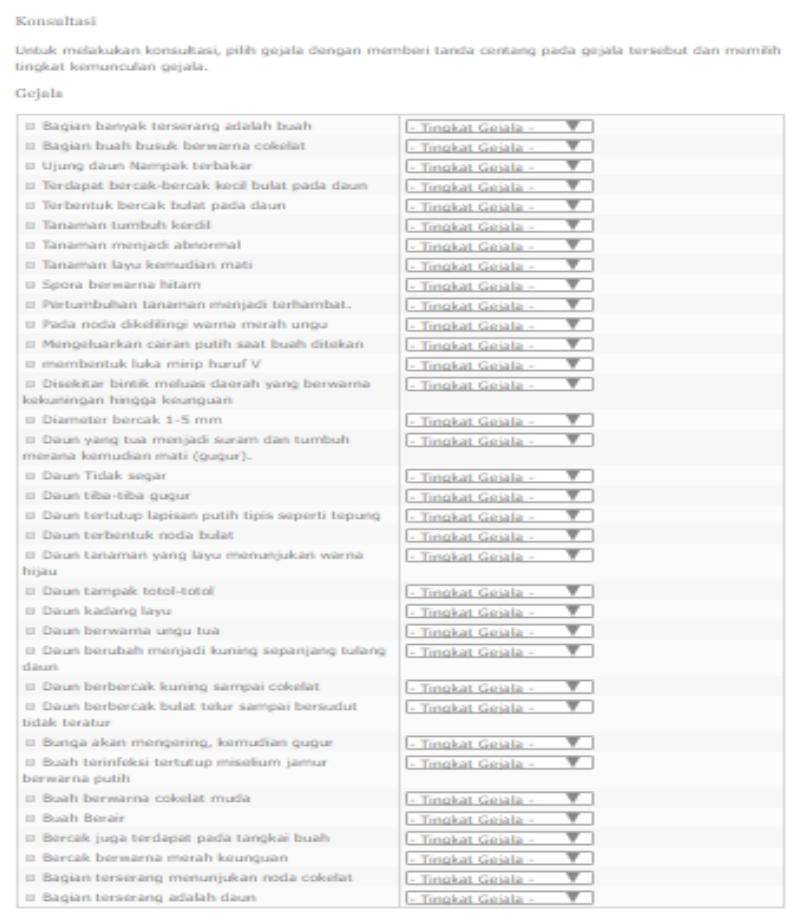

Eataken prose Giegnes

Gambar 5. Halaman Konsultasi

\subsubsection{Halaman Hasil Diagnosa}

Pada halaman hasil diagnosa merupakan hasil dari proses konsultasi yang dilakukan oleh member yang diproses oleh sistem untuk mengetahui jenis penyakit yang menyerang tanaman stroberi tersebut. Setelah member selesai memilih dan memulai proses diagnosa, maka akan ditampilkan hasil diagnosa seperti pada Gambar 6

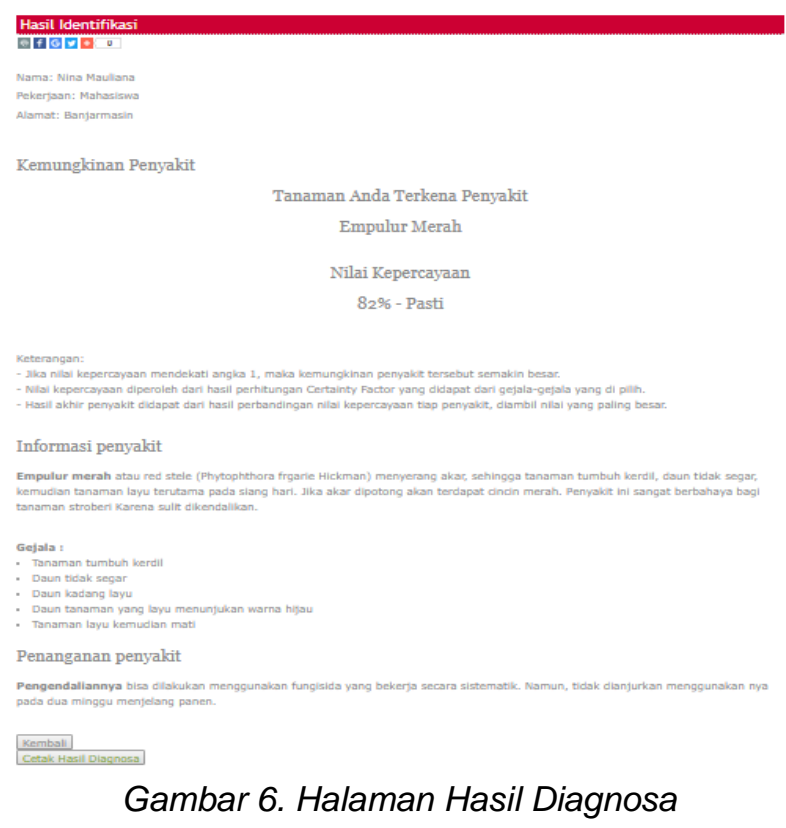

REPOSITOR, Vol. 1, No. 1, November 2019: 47-58 


\subsubsection{Halaman Utama Admin}

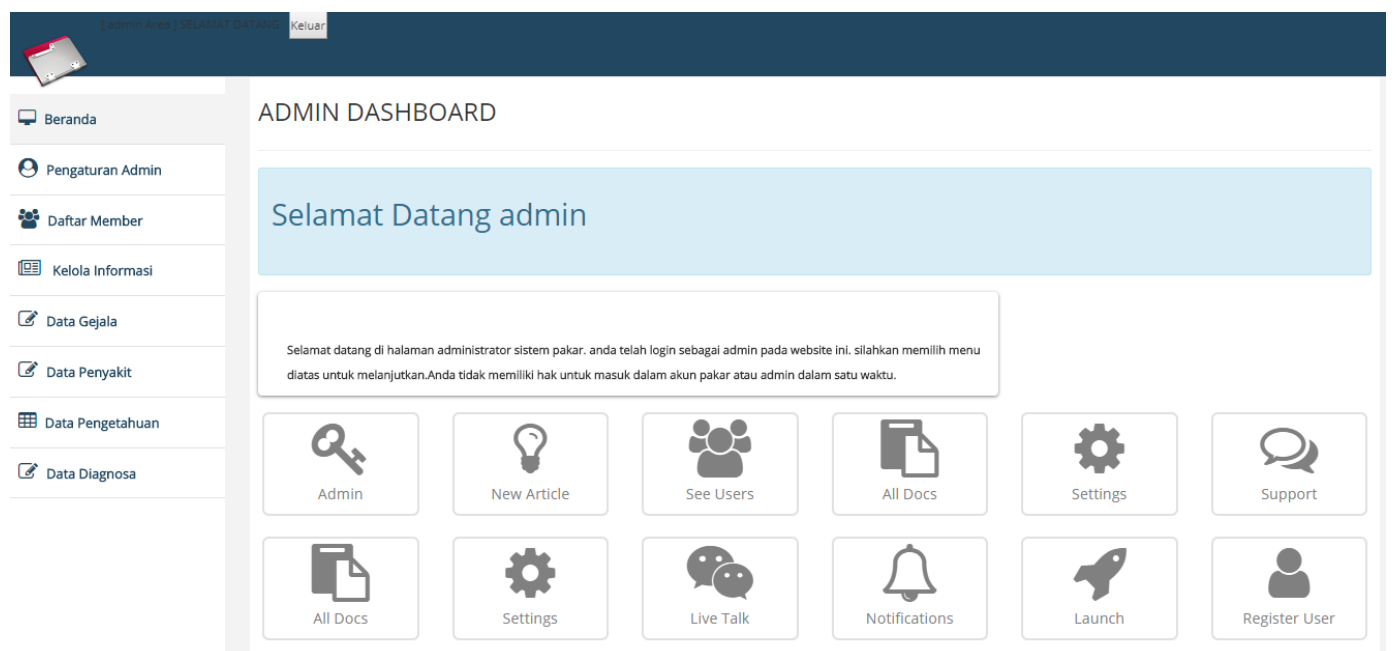

Gambar 7. Halaman Admin

Sebelumnya admin memasukkan username dan password dulu pada form login sebelum masuk pada halaman admin untuk mendapatkan hak akses penuh dalam pengelolaan sistem pakar ini. Potongan kode untuk login admin dapat dilihat pada Gambar 7.

\subsection{Pengujian Sistem}

Analisis Hasil uji coba perangkat lunak ini dilakukan untuk mengetahui apakah perangkat lunak ini adalah telah bekerja dan berjalan dengan baik sesuaidengan fungsi dan tujuan awal perencanaan atau tidak, dengan melakukan suatu pengujian terhadap program dengan metode blackbox testing dan pengujian dengan cara mencocokkan hasil diagnosa sistem dengan pakar seperti pada Tabel 2 .

\subsubsection{Kasus dan Pengujian fungsional}

Tabel 2. Hasil Pengujian Sistem Dengan Blackbox Testing

\begin{tabular}{|c|c|c|c|}
\hline No. & Fitur yang diuji & Hasil yang didapat & Kesimpulan \\
\hline 1. & $\begin{array}{l}\text { Registrasi } \\
\text { user }\end{array}$ & $\begin{array}{l}\text { Sistem dapat menerima input } \\
\text { data saat user mengisi form } \\
\text { yang disediakan }\end{array}$ & Berhasil \\
\hline 2. & Login User & $\begin{array}{l}\text { Sistem dapat menerima use } \\
\text { rname dan password yang } \\
\text { dilakukan oleh user }\end{array}$ & Berhasil \\
\hline 3. & Konsultasi & $\begin{array}{l}\text { User memilih gejala yang } \\
\text { dialami lalu menekan tombol } \\
\text { 'proses' }\end{array}$ & Berhasil \\
\hline 4. & $\begin{array}{c}\text { Hasil } \\
\text { Diagnosa }\end{array}$ & $\begin{array}{l}\text { Sistem Berhasil menampilkan } \\
\text { hasil diagnosa dan perhitungan } \\
\text { berdasarkan gejala yang dipilih }\end{array}$ & Berhasil \\
\hline 5. & $\begin{array}{c}\text { Cetak Hasil } \\
\text { Diagnosa }\end{array}$ & $\begin{array}{l}\text { Sistem Berhasil menampilkan } \\
\text { hasil diagnosa dan perhitungan } \\
\text { berdasarkan gejala yang dipilih } \\
\text { serta terdapat tombol cetak hasil } \\
\text { diagnosa untuk dapat langsung } \\
\text { mencetak laporan }\end{array}$ & Berhasil \\
\hline 6. & $\begin{array}{c}\text { Bagikan Hasil } \\
\text { Diagnosa }\end{array}$ & $\begin{array}{l}\text { Sistem Berhasil menampilkan } \\
\text { hasil diagnosa dan perhitungan } \\
\text { berdasarkan gejala yang dipilih }\end{array}$ & Berhasil \\
\hline
\end{tabular}




\begin{tabular}{|c|c|c|c|}
\hline & & $\begin{array}{l}\text { serta terdapat tombol share ke } \\
\text { berbagai media sosial. }\end{array}$ & \\
\hline 7. & $\begin{array}{l}\text { Halaman } \\
\text { Glosari }\end{array}$ & $\begin{array}{l}\text { Sistem berhasil menampilkan } \\
\text { informasi seputar gejala dan } \\
\text { penyakit tanaman stroberi, serta } \\
\text { terdapat tombol share ke } \\
\text { berbagai sosial media juga } \\
\text { terdapat tombol print untuk } \\
\text { dapat langsung mencetak artikel } \\
\text { terkait. }\end{array}$ & Berhasil \\
\hline 8. & $\begin{array}{l}\text { Halaman } \\
\text { Informasi }\end{array}$ & $\begin{array}{l}\text { Sistem berhasil menampilkan } \\
\text { informasi seputar tanaman } \\
\text { stroberi, serta terdapat tombol } \\
\text { share ke berbagai sosial media } \\
\text { juga terdapat tombol print untuk } \\
\text { dapat langsung mencetak artikel } \\
\text { terkait. }\end{array}$ & Berhasil \\
\hline 9. & $\begin{array}{l}\text { Menu login } \\
\text { admin/ }\end{array}$ & $\begin{array}{l}\text { Sistem dapat menerima } \\
\text { username dapat menerima } \\
\text { username dan password yang } \\
\text { dilakukan oleh admin untuk login }\end{array}$ & Berhasil \\
\hline 10. & $\begin{array}{l}\text { Pengelolaan } \\
\text { data Gejala }\end{array}$ & $\begin{array}{l}\text { Sistem dapat menampilkan data } \\
\text { gejala, menambah data gejala, } \\
\text { merubah data gejala }\end{array}$ & Berhasil \\
\hline 11. & $\begin{array}{l}\text { Pengelolaan } \\
\text { Data Penyakit }\end{array}$ & $\begin{array}{l}\text { Sistem dapat menampilkan data } \\
\text { penyakit, menambah data } \\
\text { gejala, merubah data Penyakit }\end{array}$ & Berhasil \\
\hline 12. & $\begin{array}{l}\text { Pengelolaan } \\
\text { Data } \\
\text { pengetahuan }\end{array}$ & $\begin{array}{l}\text { Sistem dapat menampilkan data } \\
\text { pengetahuan, menambah data } \\
\text { gejala, merubah data } \\
\text { pengetahuan }\end{array}$ & Berhasil \\
\hline 13. & $\begin{array}{l}\text { Pengelolaan } \\
\text { Data Member }\end{array}$ & $\begin{array}{l}\text { Sistem dapat menampilkan data } \\
\text { member, dapat mencari data } \\
\text { member berdasarkan nama dan } \\
\text { dapat menghapus member } \\
\text { terdaftar }\end{array}$ & Berhasil \\
\hline 14. & $\begin{array}{l}\text { Pengelolaan } \\
\text { Berita }\end{array}$ & $\begin{array}{l}\text { Sistem dapat menampilkan data } \\
\text { artikel, menambah data, } \\
\text { merubah data artikel }\end{array}$ & Berhasil \\
\hline 15. & $\begin{array}{l}\text { Cetak } \\
\text { Laporan }\end{array}$ & $\begin{array}{l}\text { Sistem dapat menampilkan data } \\
\text { laporan member yang } \\
\text { melakukan diagnosa, daftar } \\
\text { gejala dan daftar penyakit serta } \\
\text { terdapat tombol cetak untuk } \\
\text { langsung mencetak laporan. }\end{array}$ & Berhasil \\
\hline 16. & Menu Riwayat & $\begin{array}{l}\text { Sistem dapat menampilkan data } \\
\text { member yang telah melakukan } \\
\text { dignosa }\end{array}$ & Berhasil \\
\hline 17. & Menu Logout & $\begin{array}{l}\text { Sistem otomatis keluar dari } \\
\text { menu home. }\end{array}$ & Berhasil \\
\hline
\end{tabular}

\subsubsection{Kasus dan Pengujian Pakar}

Tabel 3. Pengujian Akurasi Hasil Diagnosa Sistem dan Pakar

\begin{tabular}{|c|c|c|c|c|}
\hline & & & & \\
\hline No. & Gejala yang dialami & $\begin{array}{c}\text { Diagnosa } \\
\text { Sistem }\end{array}$ & $\begin{array}{c}\text { Diagnosa } \\
\text { Pakar }\end{array}$ & $\begin{array}{c}\text { Hasil } \\
\text { Perbandingan }\end{array}$ \\
\hline
\end{tabular}

REPOSITOR, Vol. 1, No. 1, November 2019: 47-58 


\begin{tabular}{|c|c|c|c|c|c|}
\hline 1 & $\begin{array}{l}\text { a. } \\
\text { b. } \\
\text { c. } \\
\text { d. } \\
\text { e. }\end{array}$ & $\begin{array}{l}\text { Daun tidak segar } \\
\text { Daun kadang layu } \\
\text { Daun tanaman yang } \\
\text { layu menunjukan } \\
\text { warna hijau } \\
\text { Tanaman layu } \\
\text { kemudian mati } \\
\text { Tanaman tumbuh } \\
\text { kerdil }\end{array}$ & $\begin{array}{l}\text { Empulur } \\
\text { Merah }\end{array}$ & $\begin{array}{l}\text { Empulur } \\
\text { Merah }\end{array}$ & Sesuai \\
\hline 2 & $\begin{array}{l}\text { a. } \\
\text { b. } \\
\text { c. }\end{array}$ & $\begin{array}{l}\text { Daun berbercak } \\
\text { kuning sampai coklat } \\
\text { Daun kadang layu } \\
\text { Tanaman layu } \\
\text { kemudian mati }\end{array}$ & $\begin{array}{c}\text { Layu } \\
\text { Verticilium }\end{array}$ & $\begin{array}{c}\text { Layu } \\
\text { Verticilium }\end{array}$ & Sesuai \\
\hline 3 & $\begin{array}{l}\text { a. } \\
\text { b. } \\
\text { c. } \\
\text { d. }\end{array}$ & $\begin{array}{l}\text { Bagian terserang } \\
\text { adalah daun } \\
\text { Bunga akan } \\
\text { mengering kemudian } \\
\text { gugur } \\
\text { Daun tertutup } \\
\text { lapisan putih tipis } \\
\text { seperti tepung } \\
\text { Daun tiba-tiba gugur }\end{array}$ & $\begin{array}{l}\text { Embun } \\
\text { Tepung }\end{array}$ & $\begin{array}{l}\text { Embun } \\
\text { Tepung }\end{array}$ & Sesuai \\
\hline 4 & $\begin{array}{l}\text { a. } \\
\text { b. } \\
\text { c. } \\
\text { d. } \\
\text { e. }\end{array}$ & $\begin{array}{l}\text { Bercak Berwarna } \\
\text { merah keunguan } \\
\text { Bercak juga terdapat } \\
\text { pada tangkai buah } \\
\text { Daun berwarna ungu } \\
\text { tua } \\
\text { Diameter bercak } 1-5 \\
\text { mm } \\
\text { Terdapat bercak- } \\
\text { bercak kecil bulat } \\
\text { pada daun }\end{array}$ & Noda Merah & Noda Merah & Sesuai \\
\hline 5 & $\begin{array}{l}\text { a. } \\
\text { b. } \\
\text { c. } \\
\text { d. } \\
\text { e. } \\
\text { f. }\end{array}$ & $\begin{array}{l}\text { Bagian Banyak } \\
\text { terserang } \\
\text { adalahbuah } \\
\text { Buah berair } \\
\text { Buah berwarna } \\
\text { cokelat muda } \\
\text { Mengeluarkan cairan } \\
\text { putih saat buah } \\
\text { ditekan } \\
\text { Buah terinfeksi } \\
\text { tertutup miselium } \\
\text { jamur berwarna putih } \\
\text { Spora berwarna } \\
\text { hitam }\end{array}$ & $\begin{array}{c}\text { Busuk } \\
\text { Rizopus }\end{array}$ & $\begin{array}{c}\text { Busuk } \\
\text { Rizopus }\end{array}$ & Sesuai \\
\hline 6 & $\begin{array}{l}\text { a. } \\
\text { b. } \\
\text { c. }\end{array}$ & $\begin{array}{l}\text { Daun berbercak } \\
\text { bulat telur } \\
\text { Pada noda dikelilingi } \\
\text { warna merah ungu } \\
\text { Disekitar bintik } \\
\text { meluas daerah yang } \\
\text { berwarna } \\
\text { kekuningan hingga } \\
\text { keunguan }\end{array}$ & $\begin{array}{l}\text { Daun } \\
\text { Gosong }\end{array}$ & $\begin{array}{l}\text { Daun } \\
\text { Gosong }\end{array}$ & Sesuai \\
\hline
\end{tabular}




\begin{tabular}{|c|c|c|c|c|c|}
\hline & & $\begin{array}{l}\text { Daun yang tua } \\
\text { menjadi suram dan } \\
\text { tumbuh merana } \\
\text { kemudian mati }\end{array}$ & & & \\
\hline 7 & $\begin{array}{l}\text { a. } \\
\text { b. } \\
\text { c. } \\
\text { d. }\end{array}$ & $\begin{array}{l}\text { Daun terbentuk noda } \\
\text { bulat } \\
\text { Pada noda dikelilingi } \\
\text { warna merah ungu } \\
\text { Membentuk luka } \\
\text { mirip Huruf } V \\
\text { Bagian terserang } \\
\text { adalah daun }\end{array}$ & Hawar Daun & Hawar Daun & Sesuai \\
\hline 8. & $\begin{array}{l}\text { a. } \\
\text { b. } \\
\text { c. } \\
\text { d. }\end{array}$ & $\begin{array}{l}\text { Daun terbentuk noda } \\
\text { bulat } \\
\text { Pada noda dikelilingi } \\
\text { warna merah ungu } \\
\text { Disekitar bintik } \\
\text { meluas daerah yang } \\
\text { berwarna } \\
\text { kekuningan hingga } \\
\text { keunguan } \\
\text { Daun yang tua } \\
\text { menjadi suram dan } \\
\text { tumbuh merana } \\
\text { kemudian mati }\end{array}$ & $\begin{array}{l}\text { Daun } \\
\text { Gosong }\end{array}$ & $\begin{array}{l}\text { Daun } \\
\text { Gosong }\end{array}$ & Sesuai \\
\hline 9. & $\begin{array}{l}\text { a. } \\
\text { b. } \\
\text { c. }\end{array}$ & $\begin{array}{l}\text { Ujung daun Nampak } \\
\text { terbakar } \\
\text { Daun tidak segar } \\
\text { Pertumbuhan } \\
\text { tanaman menjadi } \\
\text { terhambat }\end{array}$ & Tip Burn & Tip Burn & Sesuai \\
\hline 10 & $\begin{array}{l}\text { a. } \\
\text { b. } \\
\text { c. } \\
\text { d. }\end{array}$ & $\begin{array}{l}\text { Tanaman tumbuh } \\
\text { kerdil } \\
\text { Tanaman menjadi } \\
\text { abnormal } \\
\text { Daun berubah } \\
\text { menjadi kuning } \\
\text { sepanjang tulang } \\
\text { daun } \\
\text { Daun tampak totol- } \\
\text { totol }\end{array}$ & Virus & Virus & Sesuai \\
\hline 11 & $\begin{array}{l}\text { a. } \\
\text { b. } \\
\text { c. } \\
\text { d. } \\
\text { e. }\end{array}$ & $\begin{array}{l}\text { Buah berair } \\
\text { Buah berwarna } \\
\text { cokelat muda } \\
\text { Mengeluarkan cairan } \\
\text { putih saat buah } \\
\text { ditekan } \\
\text { Buah terinfeksi } \\
\text { tertutup miselium } \\
\text { jamur berwarna putih } \\
\text { Bagian buah busuk } \\
\text { berwrna cokelat }\end{array}$ & $\begin{array}{c}\text { Busuk } \\
\text { Rizopus }\end{array}$ & $\begin{array}{l}\text { Busuk } \\
\text { Rizopus }\end{array}$ & Sesuai \\
\hline 12 & $\begin{array}{l}\text { a. } \\
\text { b. } \\
\text { c. }\end{array}$ & $\begin{array}{l}\text { Daun Kadang Layu } \\
\text { Tanaman tumbuh } \\
\text { kerdil } \\
\text { Bercak juga terdapat } \\
\text { pada tangkai buah }\end{array}$ & Noda Merah & $\begin{array}{l}\text { Empulur } \\
\text { Merah }\end{array}$ & Tidak Sesuai \\
\hline
\end{tabular}

REPOSITOR, Vol. 1, No. 1, November 2019: 47-58 
d. Daun tanaman yang layu berwarna hijau

e. Terdapat bercakbercak kecil bulat pada daun

f. Tanaman tumbuh kerdil

a. Daun berbercak bulat telur

b. Pada noda dikelilingi warna merah ungu

c. Disekitar bintik meluas daerah yang berwarna
d. Daun yang tua menjadi suram dan tumbuh merana kemudian mati
e. Ujung daun Nampak terbakar

Dari hasil Tabel 3, dapat disimpulkan bahwa akurasi pada aplikasi ini berdasarkan 13 sampel untuk diagnosa penyakit pada tanaman stroberi, menggunakan Persamaan 4 adalah sebagai berikut

$$
\text { NNilai Akurasi }=12 / 13 \times 100 \%=92 \%
$$

\section{Kesimpulan}

Berikut kesimpulan yang didapatkan berdasarkan hasil penelitian, Analisa dan perancangan implementasi sistem, juga pengujian pada sistem pakar diagnosa penyakit tanaman stroberi menggunakan metode certainty factor adalah sebagai berikut:

1. Membangun sebuah aplikasi sistem pakar yang digunakan untuk mendiagnosis penyakit tanaman stroberi dengan memasukkan nilai keyakinan gejala dari tiap gejala tanaman yang terserang suatu penyakit untuk dilakukan perhitungan menggunakan metode certainty factor untuk memperoleh nilai keyakinan tertinggi sebagai hasil diagnosa sistem.

2. Hasil Pengujian aplikasi ini dapat berjalan dengan baik sesuai kebutuhan sistem yang berdasarkan fungsionalitas sebesar $100 \%$.

3. Berdasarkan pengujian akurasi pada aplikasi ini dengan menggunakan 13 sampel didapat tingkat keberhasilan sistem pakar dari presentase pengujian dari seorang pakar mencapai akurasi $92 \%$.

\section{Daftar Notasi}

H : Hipotesa atau konklusi yang dihasilkan.

E : Evidence atau Fakta

$\mathrm{CF} \quad$ : Tingkat keyakinan terjadinya hipotesa $\mathrm{H}$ akibat adanya fakta - fakta $\mathrm{E} 1 \mathrm{~s} / \mathrm{d} \mathrm{En}$.

$\mathrm{CF}(\mathrm{E}, \mathrm{e})$ : certainty factor fakta $\mathrm{E}$ yang dipengaruhi oleh fakta e.

$\mathrm{CF}(\mathrm{H}, \mathrm{E})$ : certainty factor hipotesis dengan asumsi fakta diketahui dengan pasti, yaitu ketika $\mathrm{CF}(\mathrm{E}, \mathrm{e})=1$.

$\mathrm{CF}(\mathrm{H}, \mathrm{e})$ : certainty factor hipotesis yang dipengaruhi oleh fakta e.

\section{Referensi}

[1] Rukmana, H.R, Stroberi Budidaya dan Pascapanen. Yogyakarta : Kanisius, 1998.

[2] Durkin, John, Expert Systems Design and Development. New Jersey : Prentice Hall International Inc, 1994

[3] Turban,Efraim, Decision Support System and Expert System. New Jersey : Prentice Hall International, 1995 
[4] Kusumadewi, Sri, Artificial Intelligence. Yogyakarta : Graha IImu, 2003.

[5] Agus Kurnia, Petunjuk Praktis Budi Daya Stroberi. Jakarta : Agro Medika Pustaka,2005

[6] A. Pranata, "Penyakit Pada Tanaman Stroberi Berbasis Web," STIMIK ATMA LUHUR PANGKALPINANG, 2015.

[7] G. V. Daniel, "Implementasi Sistem Pakar untuk Mendiagnosis Penyakit dengan Gejala Demam Menggunakan Metode Certainty Factor", Jurnal Informatika, Vol. 6 No.1, 2010.

[8] E. Ongko, "Perancangan Sistem Pakar Diagnosa Penyakit Pada Mata," Jurnal Time, Vol.II No,2, pp 10-17, 2013.

[9] S. Rohajawati and R. Supriyanti, "Sistem Pakar : Diagnosis Penyakit Unggas Dengan Metode Certainty Factor, CommlT. Vol.4 No.1, pp 41-46, 2010

[10] H. Rohayani, "Analisis Sistem Pendukung Keputusan Dalam Memilih Program Studi Menggunakan Metode Logika Fuzzy," Jurnal Sistem Informasi (JSI), Vol.5 No.1, pp.530539, 2013.

[11] Balitjestro.

http://balitjestro.litbang.pertanian.go.id/mengenal-stroberi 